Madrygal. Revista de Estudios Gallegos

ISSN: 1138-9664

\title{
Quenda de agarda
}

Miriam Ferradáns

\section{I}

O relato repítese cada certo tempo. Papá ou mamá van para o hospital.

Esa noite, túmbome na súa cama.

Se meto a man baixo a almofada sinto a cabeza dun neno, a súa forma.

Logo as horas transcorren insípidas.

Imaxino o día que virá, ensaio conversas, vexo unha rata cruzarse na autoestrada.

Cando non están, a luz do corredor queda prendida. A luz de fóra, queda prendida.

Somos o faro dos derrotados. Só a iso ninguén nos vence.

A miña palma de cunco, acariña o algodón portugués.

A noite nunca remata.

\section{II}

Exhibir a dor ten as súas regras. Todo se aprende.

Fronte a porta, un facsímil de Van der Weyden.

Axiña aparto a ollada. Nesta casa non se chora.

Por que sempre se poñen enfermos?

Cando era nena quedaba apoiada contra o marco

da porta. Logo discutían o meu reparto.

A todos lles importaba menos a min.

Se a rata me comera os pés, ninguén me levaría. 
Nunca se preocuparon de mentirme.

O primeiro médico que me calmou tiña sesenta e oito anos.

Non foi amable senón eficaz.

-A túa nai curará. Viñeches soa?

Nesta casa non se chora.

De maior quero un vestido azul coma o da virxe de Van der Weyden.

\section{III}

Debaixo da cama, escondo unha rosa bendicida.

Se non me agarro á fe, non teño nada.

Desde que son adulta, marchamos as dúas.

No limiar seguen quedando as miñas ganas de vivir.

\section{IV}

Teño medo pero nunca llo digo a ninguén.

Ensináronme a que facelo non cura.

Non probo a desobedecer

porque estou cansa e son supersticiosa.

Quizais o estea por selo.

Cruzo os dedos cada vez que un médico entra no cuarto.

Creo que se dan conta mentres as súas palabras caen polo chan.

Se pasara unha rata, comeríame os pés.

Pregunto canto dudo, logo sorrío aos meus pais e cóntolles mentiras.

Con eles funciona. 
V

Advírtenme que non se pode crer en Deus e na sorte.

Nada me importa máis que salvalos.

VI

Cando miña nai marcha, eu enfermo sen que o note.

Adelgazo e cáeme o pelo.

Choro e cóntollo á xente.

Desobedezo.

Cada vez a fe funciona menos.

Tampouco é verdade que o conte,

contéñome o suficiente para mentirlles

tamén a eles e explicarlles detalles banais

de soros e salas de agarda.

Estou cansada.

\section{VII}

Durmo cunha rosa bendicida debaixo do colchón.

Teño medo de que os meus pais morran pola noite. 
